\title{
KULTURÁLIS ÉRTÉKEINK MEGBECSÜLÉSÉRŐL
}

\section{(ECY MACYAR HUMANISTA AFRIKA-KUTATÓ ÉLETMÜVE ÉLETRE KEL?)}

\section{BIERNACZKY SZILÁRD}

Az elmúlt években, a Magyar Afrika Tudástár elektronikus könyvtár megalapítása és folyamatos feltöltése közben, mindinkább szembesülnöm kellett azzal a ténnyel, hogy még egy olyan (nálunk!) marginális kulturális-tudományos területen is, mint az „Afrika-tanulmányok” (vagy másként egyszerüen a hazai Afrika iránti érdeklödés) mérhetetlen gazdagsággal sorjáznak az elfeledett vagy soha számba nem vett hazai tevékenységek és az azt kísérő, gyakran igen értékes (írás)művek. És óhatatlanul merült fel mind gyakrabban bennem a nyugtalanító gondolat: vajon jól gazdálkodunk-e - nem is oly ritkán egyetemes szintünek érzett, vélt vagy egyértelmüen annak tekinthető - értékeinkkel?

A két világháború között a határokon túlra tekintő érdeklődés beszűkülése miatt talán csak az olasz-etióp háború fordította a honi szemeket és füleket erőteljesebben a fekete földrész felé. A Kádár-korszak során viszont hellyel-közzel mind a sajtóban, mind a tudományos életben fel-felbukkant Magyar László vagy Torday Emil neve, és a persze továbbra is körüllengte a madagaszkári királyság alaptalan mítosza Benyovszky Móricot. Különösen sokat tett viszont a régi magyar, közöttük afrikai utazók fényre hozásáért Tardy Lajos. Lásd: a 17. századi és Egyiptomot megjáró Huszthy György portai követ, a 18. századi Geramb Ferdinand tábornok, majd trappista szerzetes, Baron Tott avagy Tóth Ferenc, a Dardanellák védője, majd francia diplomata Egyiptomban, valamint az észak-afrikai kútfők között számon tartott Dombay Ferenc, Mária Terézia marokkói diplomatája nevét, és persze még másokat. $\mathrm{S}$ Tardy maga nem átallott az akkori Magyar Nemzetbe népszerüsítő cikkeket is írni müvelődéstörténetünknek ezekről a mindenképpen figyelmet érdemlő alakjairól.

De már nem jutott el a fényre hozásig pl. a Dreyfus-perben elmarasztalt ValsinEsterházy apjának, Louis Joseph Ferdinand Walsin-Esterhazynak (1807-1857), mondhatni, történelmi és egyúttal tudományos szereplése, aki francia állampolgárként, miután 18 évet töltött Algériában, a hadosztályparancsnokságig vitte a krimi háborúban, de onnan súlyosan megbetegedve tért vissza, és halt meg ötven évesen. Maga után hagyott azonban két mára francia és arab kutatók által is idézett könyvet: az egyik a korábban törökök által leigázott Algériába vezet, míg a másik a francia gyarmatosítás évtizedeit idézi fel...

S ha áttérünk a 19. századra, az elfeledettek névsora mind gazdagabbá válik. 
Érték-gazdálkodásunk problémáit azonban most egyetlen jeles magyar tudós, a kiemelkedő jelentőségü kongói terepmunkás, etnológus, Torday Emil (1875-1931) életmüvének körüljárásával szeretném szemléltetni, akinek még alapvető életrajzi adataira is csak most, Földessy Edina könyve (Torday Emil kongói gyüjteménye, Néprajzi Múzeum kiadása, 2015) kapcsán derült fény. Magam a Torday névnek bedőlve erdélyi kollégákkal nyomoztattam utána (hiszen ismert a méltatlan történet, a világháború után, ugyancsak neve alapján, birtokot ajánlották a számára, ha felveszi a román állampolgárságot, amelyre természetesen nemet mondott, hiszen még az angol állampolgárságot sem volt hajlandó magyarsága megtartása érdekében felvenni).

Jeles Afrika-kutatónk eredeti neve azonban - az említett monográfia szerzőjének kutatómunkája nyomán - immár ismertté vált. Valójában Böhm Emil néven látott napvilágot 1875. június 22-én. És idősebb, valamint fiatalabb fiútestvérével együtt Böhm Lajos biztosítási hivatalnok és a Csáktornyáról származó Mannheimer Erzsébet nevü szülők gyermekeként született. Nevük onnan származik, hogy 1890-ben belügyminisztériumi rendelettel azt Tordai-ra változtatták. Az y-ra alakítás oka nem ismert.

Tordayról dióhéjban itt most csak annyit, 1900 és 1909 között három utazást tett az egykori Belga-Kongóba, előbb belga megbízásból, majd az angol tudományos

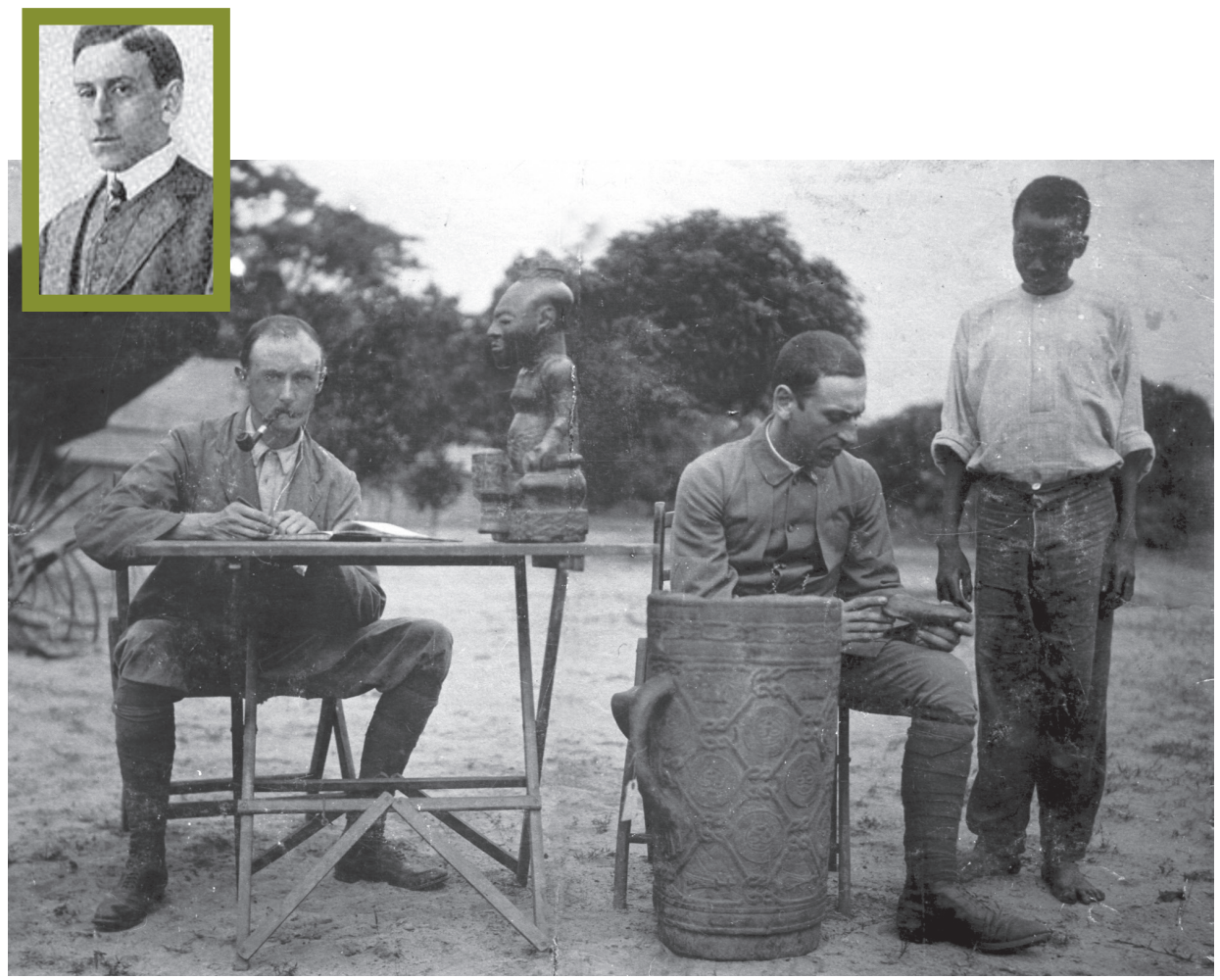

^ Torday Emil. Forrás: Néprajzi Múzeum (neprajz.hu) és Wikipedia (arckép). 
intézmények (Royal Anthropological Institute, British Museum) támogatásával. Mivel utolsó útja végén egy orrszarvú súlyosan megsebesítette, amelynek nyomait egész további élete során viselte, így minden igyekezete ellenére sem tudott többé szeretett Afrikájába visszatérni. Élete hátralévő 22 évében viszont 8 könyvet, 40-45 tanulmányt és mintegy 50-60 kisebb cikket, ismertetést publikált. A Spencer Társaság felkérésére pedig élete utolsó éveiben elkészítette monumentális „Afrikai fajok” (African Races, 1930) kiemelkedő jelentőségü elméleti összehasonlító munkáját, amely mellesleg a néprajzi kartográfia egyik előfutárának számít. Könyveit és tanulmányait mindmáig folyamatosan idézik a világ számos országának kutatói.

John Mack, a British Museum egykori muzeológusa (ma a University of East Anglia egyetem professzora) kezdeményezésére 1990-ben egy nagyjelentőségű kiállítás megrendezésére került sor Torday rendkívül értékes és gazdag néprajzi gyüjtéséből, amely kutatónk életművének valóságos reneszánszát indította el (Emil Torday and the Art of the Congo címmel jelent meg maga a katalógus). A müvészeti tárgyak és a gazdag fotóanyag mellett müvei többek között olyan diszciplínáknak a forrásaivá lettek mára, mint a szóbeli történelemkutatás, a folklorisztika, az etnolingvisztika, az etnomatematika vagy az embertan.
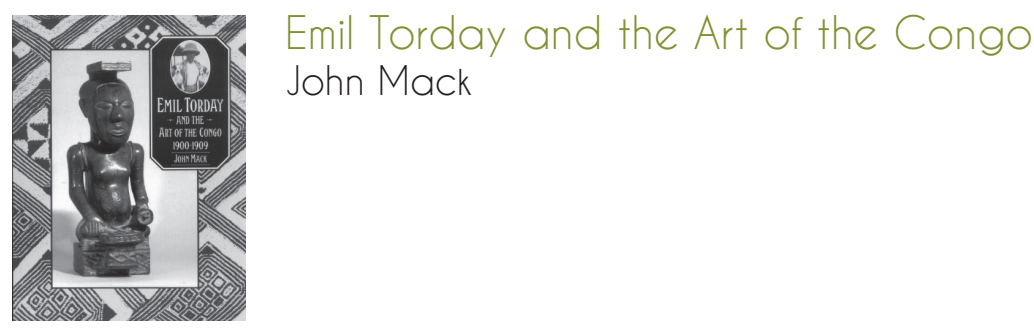

De saját hazánkra térve, kétségtelenül dicséretes tények sorát ismertethetjük itt az elmúlt évekből. Kubassek János, a Földrajzi Múzeum igazgatója tényfeltáró és összegező tanulmányait. Egy igen értékes kiállítást, amelyet Régi Tamás régi és új magyar kutatók afrikai fotóiból állított össze a Történeti Múzeumban, és ezen számos híres Torday-fotó is szerepelt. Egyedülállóan fontosnak számít e sorban Szilasi Ildikó jelentős figyelmet keltő akciósorozata, expedíciója Kongóba, majd az egész országot bejáró kiállítása, végül a kitünő (National Geographic) fotóssal, Lóránt Attilával együtt készített gyönyörü album (2010), amelyeknek vezérlő gondolata egyképpen: „100 év azonosság, 100 év változás: Torday Emil nyomában Kongóban” volt.

Napjaink igen fontos újdonsága a már említett mü, Földessy Edina monografikus albuma, amelynek elkészítésére indokot jeles kutatónk Magyarországnak juttatott és ma a Néprajzi Múzeumban őrzött gazdag gyüjteményrésze adott. A kötet a közel félszáz tárgyból mintegy 100-at mutat be kitünő fotókon, részletes magyarázatokkal füszerezve. De legalább ilyen értékes a két nyelven közreadott igen alapos bevezetö, amely Torday életrajzára, afrikai érdeklődése kialakulására, útjaira, londoni kutatói évtizedeire, munkásságára és természetesen az itthon, illetve a világ több helyén őrzött gyüjteményrészeire is kitér. 


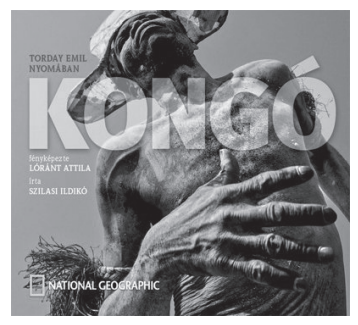

\section{Torday Emil nyomában - Kongó \\ Szilasi Ildikó \\ Fotó: Lóránt Attila}

Azt is mondhatjuk, ebben a tekintetben, mi magyarok léptünk elsőként, hiszen a világhírü Torday-gyüjtemény anyagából még a British Museum se adott ki önálló albumot. Más kérdés, hogy nekünk magyaroknak volna a feladatunk kötetbe összegyüjteni valahára a talán legnagyobb magyar afrikanistának tekinthető (egyébként kora sok más terepmunkára vállalkozó etnológusához hasonlóan autodidacta) tudósunk igen értékes, máig jól hasznosítható írásait, amelyek akár olyan kényes kérdésekre is kitérnek, mint az emberevés, a méregpróba vagy a szexualitás. Továbbá három francia és három angol nyelvű művét is ki kellene adni végre magyar nyelven. (Két magyar nyelvü népszerüsítő jellegü könyvét, amelyet egykor Halász Gyula kivonatolt az említett opusokból, hazai kiadók az utóbbi években többször is felvettek terveik listájába, de végül a megjelentetés nem következett be. Igaz viszont, hogy mind a debreceni nemzeti könyvtár, mind az OSZK felhelyezte azokat elektronikus gyüjteményébe.)

Napjainkat terrorizmus és a vele járó agresszivitás, brutalitás és vandalizmus szabdalja. Torday Emilt, aki arról volt nevezetes már a saját korában londoni körökben, hogy Afrikában nem gyarmatosítóként lépett fel, hanem az afrikaiak barátjává lett, „nagy fehér bíróként” törzseket békített össze, háborúkat akadályozott meg jártában-keltében, a kubák természetes kulturáltságú, demokratizáló újdonságokat bevezető királyával szinte örök barátságot kötött (később a gyarmatosítók ostobasága miatt bekövetkezett korai halála miatt kesereg egy helyütt), - egyszóval őt mint egy fényt sugárzó „magyar békesség-jelképet” kellene felmutatnunk itthon és világszerte. De ehhez azonban csakis az életmü minél teljesebb és szélesebb körü gondozásával, hazai és külhoni megismertetésével juthatunk el!
A szerzőröl
About the Author
néprajzkutató, afrikanista
Ethnographer, Africanist
ny. egy. docens, kandidátus
Retired Associate Professor, C.Sc.
felelōs szerkesztō (AHU Magyar
Executive Editor (AHU Hungarian
Afrika-Tudás Tár elektronikus
Africa Knowledge Store, e-library)
könyvtár)

(a) biernaczky.szilard@munduspress.hu 